This PDF is a selection from a published volume from the National Bureau of Economic Research

Volume Title: Measuring and Managing Federal Financial Risk

Volume Author/Editor: Deborah Lucas, editor

Volume Publisher: University of Chicago Press

Volume ISBN: 0-226-49658-9

Volume URL: http://www.nber.org/books/luca07-1

Conference Date: February 8-9, 2007

Publication Date: February 2010

Chapter Title: Bringing Financial Literacy to Washington

Chapter Author: Peter R. Fisher

Chapter URL: http://www.nber.org/chapters/c3081

Chapter pages in book: $(13$ - 19) 


\section{Bringing Financial Literacy \\ to Washington}

Peter R. Fisher

By focusing on "measuring and managing federal financial risk," you are asking the right questions about our financial future. I hope you come up with some good answers soon. The broader question you address is this: can the Federal Government become financially literate? Or, more importantly, can it learn to behave in a financially literate manner?

Reasonable people may conclude that the best answer to this question is "No, it cannot: abandon all hope, ye who enter here." That option is not open to me and I hope not to you. Those of us who would like to ensure that our national government's financial resources can be mobilized for our collective needs in the future must be concerned.

In particular, those of us who fear that we are on an unsustainable path of accumulating federal liabilities - current, contingent, and the futurebear the burden of articulating a theory of the sustainable path of federal liabilities. We bear this burden because many of our fellow citizens think we are the shepherd boy crying wolf: the Federal Government appears to have no difficulty sustaining its liabilities.

Before I get going, let me come clean: I do not have a theory of the sustainable path of federal liabilities. I only have a few stories and a few suggestions.

My suggestions, in summary, are as follows:

1. Do not wait for the bond market to help us out; that is not its job.

2. We need to improve the process. This is not about a single set of true numbers but about more (and more useful) information.

Peter R. Fisher is Managing Director at BlackRock, Inc.

This chapter is based on the keynote remarks given at the conference on Measuring and Managing Federal Financial Risk, Zell Center for Risk Research, Kellogg School of Management, Northwestern University, February 8, 2007. 
3. It is not just about process, it is about substance: this is a very real fight over the allocation of resources.

Now for the stories.

In the fall of 2001, as a newly confirmed under secretary, my first real assignment from the White House was to persuade Congress not to enact a loan guarantee program for the airline industry following 9/11. My second assignment was to help implement the loan guarantee program that Congress enacted.

Over the following months, I found myself awkwardly defending the federal fisc from both on- and off-balance sheet attacks, including Federal Deposit Insurance Corporation (FDIC) "reform," Pension Benefit Guarantee Corporation (PBGC) "insolvency," direct lending to absorb the cost of salmon spawning during a drought, expansion plans for student loan guarantees, terrorism risk insurance, and the decaying finances of the Postal Service. With each new topic I confronted, I tried to engage my counterparts in the language of finance, risk, and exposure but found myself treated as if I were speaking a foreign language completely unrecognizable to the indigenous population.

So, in response, I did what every under secretary learns to do when backed into a corner: I gave a speech, somewhere out of town. In it, I compared the Federal Government to "a gigantic insurance company (with a sideline business in national defense and homeland security) which does its accounting on a cash basis - only counting premiums and payouts as they go in and out the door." For good measure, I noted: "An insurance company with cash accounting is not really an insurance company at all. It is an accident waiting to happen."

This was a clever thing to say. So clever, in fact, that a number of friends called to offer me employment in anticipation of my dismissal.

While it may have been clever at the time, it is worth asking now, some years later, whether I still think it is an accurate or useful metaphor. Upon even more sober reflection, I would say that in many ways I think it isalthough in one important way it is not.

First, an insurance company with only cash accounting would not be very good at pricing and managing the exposures it takes on, as it would have little information and insufficient incentives to concern itself with risk and exposure.

Likewise, it is fair to say, I think, that the Federal Government is challenged when it comes to pricing risk. Usually, Congress intervenes, sets the price too low, and limits agency discretion to adjust price in response to risk - as the history of deposit insurance and pension benefit guarantee premiums suggests.

More troublesome than the problem of Congressional handcuffs is the problem of mental handcuffs - of financial illiteracy in action. 
Consider the Pension Benefit Guarantee Corporation. For most of its history, it ran an accrual deficit. Its business of insuring the pension obligations of corporate plans with underpriced premiums meant that it did not have sufficient reserves to absorb the losses of the pension plans that it was forced to take over. While some socialization of costs like these can be accepted in principle, in this case, Congress provided no mechanism to absorb the costother than kicking it down the road. This is a bad business model.

Magically, in the late 1990s, the PBGC began to run surpluses that grew larger and larger as the economy (and stock market) strengthened. My friends and predecessors at the Treasury spent their time worrying not about PBGC solvency but rather about whether the PBGC's assets should be invested in indexed equity funds or ones managed on a discretionary basis. When the stock market bubble burst and the economy turned in 2000 and 2001, the PBGC's finances decayed rather quickly.

It is a shame that during the "years of plenty," more time was not spent thinking about the totality of the PBGC's balance sheet.

The PBGC is thrice exposed to the equity market. Its primary business is not as a pension fund but rather as a corporate guarantee fund. In simple form, on the liability side of its balance sheet, the PBGC is guaranteeing the bottom quintile of Wilshire 5000's pension fund's investments in the Wilshire 5000. What is the appropriate equity position to hold on the asset side of such a balance sheet? It is short, not long.

No wonder the PBGC seemed to be on such solid footing during the go-go 1990s. No wonder its finances deteriorated so quickly at the start of this decade.

The Federal Government is not a limited purpose organization; it has many objectives. But if it is going to take on the responsibility of intervening in a highly complex market of investment and actuarial exposures, it is a shame that it cannot do so with its eyes open to the financial risks and with the ability to structure its balance sheet accordingly. While it may be hard for some to imagine an instrumentality of the Federal Government shorting the American stock market, if our government is going to take on the responsibilities of an insurance company, doing so with one arm tied behind its back was bound to be expensive for taxpayers, pension plans, and retirees - as it has turned out in this case.

The second way the Federal Government is like a cash-accounting insurance company is that it is not in a position to understand and act upon knowledge of its aggregate position.

While progress has been made in bringing attention to the accrual position of major entitlement and benefit programs, the major players in allocating federal resources - the Office of Management and Budget (OMB), the key Congressional committees, and the Congressional leadership — do not consciously act on the basis of accrual positions as either an objective or a constraint. 
Maybe a very thin silver lining to the prescription drug benefit is that it was such a clear actuarial and accrual giveaway that Congress is less likely to sign up for such a whopper again any time soon. But I am probably being too optimistic. Let me come back to cash and accrual accounting in a moment.

There is an important way in which the Federal Government is not like an insurance company - namely in the apparent lack of market discipline. An insurance company incapable of pricing risk or acting upon knowledge of its net exposures would be punished by the capital markets and eventually find it prohibitively expensive to borrow or to raise capital. The Federal Government, however, does not seem to be subject to this form of market discipline for its recent or its future deficits.

That is right. It is not, and we should not expect it to be.

As we swung from annual surplus to annual deficits in the early years of the Bush administration, interest rates magically fell. I remember doing one of those White House lawn interviews: squinting into the camera, I heard the interviewer in my ear ask me if I was having trouble borrowing all that money now that we had plunged into deficits again. With interest rates approaching historic lows, I decided to take on something easier, and to the interviewer's surprise, switched the subject to accounting for corporate stock options.

If we want useful information about the sustainable path of federal liabilities, I do not think we are going to find it in the bond market. This is because the term structure of yields on the least risky asset is principally determined by the expected path of monetary policy. That is why bond yields were falling as the deficits expanded earlier in this decade, and that is why Japanese interest rates are still near historic lows, even as the Japanese government runs a ratio of deficit to gross domestic product (GDP) that is roughly twice (as bad as) ours.

I say this not to suggest that we need not worry about the sustainable path of federal liabilities but rather to suggest that we need to worry even more. The bond market vigilantes are not going to help us, because they are not focused on our problem; they are focused on the Fed. If anyone wants to sit around and wait for the bond market to exert fiscal discipline without any assistance from monetary policy, then I really would recommend a field trip to Japan.

In short, I have more confidence in academia to address this problem than I do in the bond markets.

So, what is to be done? First, improve the process. I have three suggestions.

1. Do not focus on one number or set of numbers; get more information.

A zero-sum debate between cash and accrual accounting is not helpful. The answer is both. I would like to see more emphasis on accrual accounting, but I would not hide or do away with the cash budget. The scope of the 
Federal Government's future contingent liabilities has reached the point where we need some constraints placed on accrued liabilities. While we may not be ready for an accrual budget, we need more accrual-based information for decision makers.

At BlackRock, our portfolio managers have a mind-boggling array of risk measures and credit information when making a decision to buy or sell a single bond or stock. Maybe we could get Congress to consider more than one set of numbers when they allocate national resources.

2. Require "accrual accounting impact statements."

Today, we have the cash budget and ten-year cash projections. I would like to see an additional requirement that prior to Congressional votes, there be an accrual accounting impact statement of any proposed legislation, scored by the Congressional Budget Office (CBO) but consistent with the methodologies used in the Treasury's Annual Financial Report.

Thirty years ago, environmental impact statements were in their infancy. They are subject to political interference and are imperfect. But we have learned a great deal over the last thirty years, and I think we are better off for having them. Looking back over the last three decades, I am confident that our nation's finances would be better off if Congress had had to confront the accrual implications of their actions before they voted rather than after.

At the Treasury, we worked hard to get the Annual Financial Report completed in time to be released in December rather than March. We hoped that some day, Congress might take notice of the accrual positions before the start of the legislation season in January rather than when the horses were already out of the barn a few months later. It would be even better if individual bills had to be scored on their accrual implications.

Better enforced budget rules and pay-go disciplines are important. However, inside any budget, there is more than enough latitude for a misallocation of resources. It is my experience that there is no substitute for killing bad ideas one at a time - if you can.

3. We need more program-specific risk and exposure information.

When the Airline Transportation Stabilization Board was set up, the net of the statutory and regulatory guidance we got was this: lend money where private markets fear to tread, but do not take unreasonable risks with the taxpayers' money. Clearer guidance from Congress would have been helpful.

Eventually, we found our way, each board member using their own method. Options-pricing methodologies helped us enormously. For my part, I reconciled our mandate with the thought that private bankers would demand a 90 to 95 percent probability of repayment. I decided to draw the line at fifty-fifty: I needed to believe that the taxpayer had a better than fifty-fifty chance of getting repaid. I thought this was pretty generous for the Treasury. But I was still thrown out of one senator's office by the 
senator himself - red in the face and screaming at me for all in the corridors to hear-for my lack of generosity.

Risk is deviation from objective. It matters whether the objective is to ensure the survival of the equity holders of all major airlines or only the survival of sufficient air transport capacity to meet likely demand. It matters whether the goal is to make student loans even more affordable for all who want them or to make college education available for those who could not otherwise afford it at all. However you may feel about these different policy objectives, risk measures need to be designed with precision around specific program goals.

Congress wants to make murky compromises that placate as many members as possible. When they create unworkable administrative complexity or take on absurd risks and exposures, the agency head can be paraded in front of the relevant committee and blamed for the entirely predictable problems. It would be funny if it were not costing us so much money and lowering the esteem in which the Federal Government is held by the American people.

The work that the academic community is doing to devise and improve upon the risk and exposure measures that can be applied to specific programs and contingent liabilities is of vital importance. These tools are simply not going to come from anywhere else.

But this not just about process, it is about substance. This is a vicious fight over the allocation of resources. Bringing greater fiscal discipline is about changing the outcomes. It is about shifting the allocation of resources away from some things and toward other things.

Let me offer one example.

Our system of direct and indirect federal intervention in the housing market, by providing guarantees of mortgage payments, does little or nothing in my view to make homeownership more affordable. On the contrary, I think it makes homeownership less affordable for the new home buyer.

If you lower the interest rate that is applied in financing an asset, then the value of the asset goes up. If you raise the interest rate, the value goes down.

I have never been that interested in measuring the value of the subsidy provided by Fannie Mae and Freddie Mac, because I do not think that any of it flows to the net-new home buyer. I think it flows to the asset holderthe home seller. We are pumping up house prices, and it is hard to see how that makes it easier on first-time home buyers.

Our subsidy to mortgage finance simply means that we consume more housing than we otherwise would; more housing and less transportation; more housing and less energy efficiency; more housing and less education.

Rising levels of home ownership over the last fifty years are more likely to be the consequence of productivity and rising standards of living than our interventions in mortgage finance. You may not agree me with about this. You may be able to persuade me that I do not see this correctly. But in 
the terms I have laid this out, we could actually have a financially literate debate - and one with significant implications for the allocation of resources in our society.

In conclusion, let me say again, thank you for bringing your intellects to bear on the problem of measuring and managing federal financial risk.

I always told the staff at the Treasury that they were expected to be the "straight men" of the Federal Government. In defending the federal fisc, they had to play Stan Laurel while everyone else in Washington got to play Oliver Hardy.

Playing the straight man is hard work, and you need good material. Thank you for creating the material to be used by future under secretaries and future Treasury staff in trying to bring a little more financial literacy to Washington. 